\title{
A STUDY OF RISK FACTORS FOR ACUTE LOWER RESPIRATORY TRACT INFECTION AND THEIR EFFECT ON OUTCOME IN CHILDREN AGED 1 MONTH TO 5 YEARS
}

\author{
Maddi Prakash Kumar1, Chinnatambi Narayanan Mohan Chandran², Duggirala Manikyamba3 , Amujuri Krishna Prasad ${ }^{4}$, \\ G. Raja Sekhar Reddy 5
}

\begin{abstract}
${ }_{1}^{1}$ Assistant Professor, Department of Paediatrics, Rangaraya Medical College, Kakinada. ${ }^{2}$ Associate Professor, Department of Paediatrics, Rangaraya Medical College, Kakinada. ${ }^{3}$ Professor \& HOD, Department of Paediatrics, Rangaraya Medical College, Kakinada. ${ }^{4}$ Associate Professor, Department of Paediatrics, Rangaraya Medical College, Kakinada. 5Junior Resident, Department of Paediatrics, Rangaraya Medical College, Kakinada.
\end{abstract}

\begin{tabular}{l} 
ABSTRACT \\
\hline BACKGROUND \\
Acute Lower Respiratory Infection (ALRI) is a leading cause of morbidity and mortality in under five children in developing \\
countries. There is a need to explore the association between easily modifiable risk factors and occurrence of ALRI in developing \\
countries to bring down the incidence of ALRI. This study is taken up to identify the various risk factors for acute lower re spiratory \\
tract infection and their effect on severity and outcome in under five children.
\end{tabular}

\section{METHODS}

A total of 275 children of age group 1 month to 5 years were studied for various risk factors. Severity of pneumonia and duration of hospital stay were noted in each case.

\section{RESULTS}

The significant risk factors for children with pneumonia for very severe pneumonia and prolonged hospital stay were age $<12$ months, overcrowding, low socioeconomic status, use of cow dung/mud flooring, biomass fuel usage, passive smoking, LBW, partial breast feeding and no breast feeding, partial immunization, PEM and anaemia.

\section{CONCLUSION}

The present study identified many modifiable risk factors for ALRI, which had significant effect on outcome. These risk factors can be tackled through effective health education of the community and appropriate initiatives taken by the government.

\section{KEYWORDS}

ALRI, Risk Factors, Pneumonia, PEM, Anaemia.

HOW TO CITE THIS ARTICLE: Kumar MP, Chandran CNM, Manikyamba D, et al. A study of risk factors for acute lower respiratory tract infection and their effect on outcome in children aged 1 month to 5 years. J. Evolution Med. Dent. Sci. 2016;5(22):1190-1194, DOI: $10.14260 /$ jemds/2016/276

\section{INTRODUCTION}

Acute respiratory infections account for $20 \%$ to $40 \%$ of the children attending outpatient clinics and $12 \%$ to $35 \%$ of admissions of children into hospitals. India with $20.3 \%$ of under five deaths caused by pneumonia, i.e. 0.371 million deaths, tops the list and contributes $23.5 \%$ of all pneumonia deaths in the world. ${ }^{1}$ There is a need to explore the association between easily modifiable risk factors and occurrence of ALRI in developing countries to bring down the incidence of ALRI. Existing studies focused on association between these risk factors and ALRI and these are not focused on risk factors and severity of pneumonia. Therefore, we undertook this study to identify the various risk factors for acute lower respiratory tract infection and their effect on severity and outcome in under five children.

Financial or Other, Competing Interest: None.

Submission 29-01-2016, Peer Review 27-02-2016,

Acceptance 04-03-2016, Published 17-03-2016.

Corresponding Author:

Dr. G. Raja Sekhar Reddy,

Junior Resident,

Department of Paediatrics,

Rangaraya Medical College,

Kakinada.

E-mail: rajasekhar.gogireddy@gmail.com

DOI: $10.14260 /$ jemds $/ 2016 / 276$

\section{METHODOLOGY}

The present study is a hospital-based prospective observational study, which was conducted from May 2014 to Oct 2015 at Government General Hospital attached to Rangaraya Medical College, Kakinada. All children in the age group of 1 month to 5 years admitted in paediatric wards and ICU with acute lower respiratory tract infection during study period were enrolled in the study. The WHO definition of ALRI was used and all cases are graded into severe and very severe pneumonia. Children with clinical diagnosis of bronchial asthma, tuberculosis and any underlying chronic illnesses were excluded from the study.

A predesigned proforma was used to record the details of enrolled children. A detailed history was taken and physical examination was done to elicit various potential risk factors. Age of the child was recorded in completed months. A detailed history of relevant symptoms like fever, cough, rapid breathing, chest retraction, refusal of feeds, lethargy, wheezing, etc. was taken. History of upper respiratory infection in mother and siblings and family history of respiratory tract infection were also obtained. History of breastfeeding was recorded. History of smoking by various family members and details of cooking fuel used was recorded. Details of the housing conditions were also obtained. 
Overcrowding is noted if following are present ( $>6$ people in house/ $>4$ children $(<15$ years) $/>2$ people sharing bed room $/>2$ people per room). Socioeconomic status grading was done according to modified Kuppuswamy's classification.

A detailed examination of each child was done. Respiratory rate and heart rate were recorded for one minute, when the child was quiet. A detailed anthropometry was taken and malnutrition was graded according to Indian Academy of Paediatrics classification. Severity of respiratory distress was assessed in each child. Anaemia and signs of vitamin deficiencies were recorded. Haemoglobin estimation and CXR were done in all cases and other investigations were done as per requirement of individual cases. Treatment was given, clinical recovery and duration of hospital stay were noted in each case. Hospitalization for more than seven days was considered as prolonged hospital stay.
Data was recorded on a predesigned proforma and managed on Excel spread sheet. Chi square test and Fisher's exact test were used to study the association between the risk factors and outcome (Severity of pneumonia and prolonged hospital stay). 'P' value $<0.05$ was taken as significant.

\section{RESULTS}

Only children with severe and very severe pneumonia were included in the study, as only these children were admitted in hospital. A total of 275 children were enrolled in this study, of which $194(70.5 \%)$ were admitted with severe pneumonia and 81 (29.5\%) with very severe pneumonia. In the study population, $170(61.8 \%)$ children with pneumonia were $1-12$ months and 105 (38.2\%) were 13-60 months of age. ALRI was more common among infants [Table 1].

\begin{tabular}{|c|c|c|c|c|c|c|}
\hline \multicolumn{2}{|c|}{ Risk Factor } & $\begin{array}{l}\text { Admitted } \\
\text { with ALRI }\end{array}$ & $\begin{array}{c}\text { Severe } \\
\text { Pneumonia }\end{array}$ & $\begin{array}{l}\text { Very Severe } \\
\text { Pneumonia }\end{array}$ & $\begin{array}{l}\text { >7 Days of } \\
\text { Hospital Stay }\end{array}$ & $\begin{array}{l}\text { Mean Duration of } \\
\text { Hospital Stay }\end{array}$ \\
\hline \multirow{4}{*}{ AGE } & $1-12 \mathrm{~m}$ & 170 & $110(64.7 \%)$ & $60(35.3 \%)$ & $92(54.1 \%)$ & 9.8 days \\
\hline & $13-36 \mathrm{~m}$ & 88 & $71(80.7 \%)$ & $17(19.3 \%)$ & $48(54.5 \%)$ & 9.2 days \\
\hline & $37-60 \mathrm{~m}$ & 17 & $13(76.5 \%)$ & $4(23.5 \%)$ & $7(41.2 \%)$ & 10.2 days \\
\hline & P Value & & \multicolumn{2}{|c|}{$\mathrm{P}=0.024$} & $P=0.57$ & \\
\hline \multirow{3}{*}{ GENDER } & Male & 171 & $120(70.2 \%)$ & $51(29.8 \%)$ & $92(53.8 \%)$ & 9.64 days \\
\hline & Female & 104 & $74(71.2 \%)$ & $30(28.8 \%)$ & 55 (52.9\%) & 9.63 days \\
\hline & P Value & & \multicolumn{2}{|c|}{$P=0.89$} & $\mathrm{P}=0.88$ & \\
\hline \multicolumn{2}{|c|}{ Total } & 275 & $194(70.5 \%)$ & $81(29.5 \%)$ & 147 (53.4\%) & 9.64 days \\
\hline \multicolumn{7}{|c|}{ Table 1: Demographic Profile of Children with Pneumonia } \\
\hline
\end{tabular}

Among socioeconomic variables, 216 (78.5\%) children with pneumonia were living in overcrowded houses; $32.5 \%$ and 57.9\% of children with overcrowding in their houses had very severe pneumonia and prolonged hospital stay respectively, which was statistically significant [Table 2].

\begin{tabular}{|c|c|c|c|c|c|c|}
\hline \multicolumn{2}{|c|}{ Risk Factor } & \multirow{2}{*}{$\begin{array}{c}\text { Admitted } \\
\text { with ALRI } \\
\mathbf{n} \\
77\end{array}$} & \multirow{2}{*}{$\begin{array}{c}\begin{array}{c}\text { Severe } \\
\text { Pneumonia } \\
\text { n (\%) }\end{array} \\
55(71.4 \%)\end{array}$} & \multirow{2}{*}{$\begin{array}{c}\begin{array}{c}\text { Very Severe } \\
\text { Pneumonia } \\
\text { n (\%) }\end{array} \\
22(28.6 \%)\end{array}$} & \multirow{2}{*}{$\begin{array}{c}\text { >7 Days of } \\
\text { Hospital Stay } \\
\text { n (\%) }\end{array}$} & \multirow{2}{*}{$\begin{array}{c}\begin{array}{c}\text { Mean } \\
\text { Duration of } \\
\text { Hospital Stay }\end{array} \\
10.3 \text { days } \\
\end{array}$} \\
\hline \multirow{3}{*}{ Mother's literacy } & Illiterate & & & & & \\
\hline & Literate & 179 & $127(70.9 \%)$ & $52(29.1 \%)$ & $89(49.7 \%)$ & 9.25 days \\
\hline & P Value & & & $\mathrm{P}=0.54$ & $\mathrm{P}=0.34$ & \\
\hline \multirow{3}{*}{ Overcrowding } & Present & 216 & $146(67.5 \%)$ & $70(32.5 \%)$ & $125(57.9 \%)$ & 9.78 days \\
\hline & Absent & 59 & $48(81.3 \%)$ & $11(18.7 \%)$ & $22(37.3 \%)$ & 9.07 days \\
\hline & $\mathrm{P}$ value & & & $\mathrm{P}=0.039$ & $\mathrm{P}=0.004$ & \\
\hline \multirow{4}{*}{$\begin{array}{l}\text { Socioeconomic } \\
\text { class }\end{array}$} & $\begin{array}{l}\text { Lower } \\
\text { middle }\end{array}$ & 61 & $44(72.1 \%)$ & $17(27.9 \%)$ & $25(40.9 \%)$ & 9.5 days \\
\hline & $\begin{array}{l}\text { Upper } \\
\text { lower }\end{array}$ & 142 & 119 (83.8\%) & $23(16.2 \%)$ & $71(50 \%)$ & 9.66 days \\
\hline & Lower & 72 & $31(43.1 \%)$ & $41(56.9 \%)$ & $52(72.2 \%)$ & 10 days \\
\hline & $\mathrm{P}$ value & & & $\mathrm{P}=0.00001$ & $\mathrm{P}=0.0006$ & \\
\hline
\end{tabular}

Among environmental variables, 55.3\% and 68.5\% of children with mud/cow dung flooring in their house had very severe pneumonia and prolonged hospital stay, which was statistically significant; $172(62.5 \%)$ children with pneumonia lived in households using cooking fuel other than LPG; 33.7\% and $62.2 \%$ of children lived in households using cooking fuel other than LPG had very severe pneumonia and prolonged hospital stay respectively, which was statistically significant; 154 (56\%) of children with pneumonia had smokers in the household; $34.4 \%$ and $59.1 \%$ children with smokers in the household had significant risk for very severe pneumonia and prolonged hospital stay respectively, which was statistically significant [Table 3]. 


\begin{tabular}{|c|c|c|c|c|c|c|}
\hline \multicolumn{2}{|c|}{ Risk Factor } & \multirow{2}{*}{$\begin{array}{c}\begin{array}{c}\text { Admitted } \\
\text { with ALRI } \\
\mathbf{n}\end{array} \\
38 \\
\end{array}$} & \multirow{2}{*}{$\begin{array}{c}\begin{array}{c}\text { Severe } \\
\text { Pneumonia } \\
\text { n (\%) }\end{array} \\
17(44.7 \%)\end{array}$} & \multirow{2}{*}{$\begin{array}{c}\begin{array}{c}\text { Very Severe } \\
\text { Pneumonia } \\
\text { n (\%) }\end{array} \\
21(55.3 \%)\end{array}$} & \multirow{2}{*}{$\begin{array}{c}\text { >7 Days of } \\
\text { Hospital Stay } \\
\text { n (\%) } \\
26(68.5 \%)\end{array}$} & \multirow{2}{*}{$\begin{array}{c}\begin{array}{c}\text { Mean Duration of } \\
\text { Hospital Stay }\end{array} \\
10.8 \text { days }\end{array}$} \\
\hline \multirow{3}{*}{ Type of floor } & $\begin{array}{l}\text { Mud/Cow } \\
\text { dung }\end{array}$ & & & & & \\
\hline & Cement/Tiles & 237 & $178(75.1 \%)$ & $59(24.9 \%)$ & $121(51.1 \%)$ & 9.57 days \\
\hline & P value & & & $\mathrm{P}=0.001$ & $\mathrm{P}=0.03$ & \\
\hline \multirow{3}{*}{$\begin{array}{c}\text { Type of fuel } \\
\text { used }\end{array}$} & Firewood & 172 & $114(66.3 \%)$ & $58(33.7 \%)$ & 107 (62.2\%) & 10.3 days \\
\hline & LPG & 159 & $122(76.7 \%)$ & 37 (23.3\%) & $59(37.1 \%)$ & 8 days \\
\hline & P value & & & $\mathrm{P}=0.039$ & $\mathrm{P}=0.0004$ & \\
\hline \multirow{3}{*}{$\begin{array}{c}\text { Family H/o } \\
\text { smoking }\end{array}$} & $\begin{array}{c}\text { Smokers in } \\
\text { house }\end{array}$ & 154 & $101(65.6 \%)$ & 53 (34.4\%) & 91 (59.1\%) & 9.6 days \\
\hline & Not present & 121 & $93(76.9 \%)$ & $28(23.1 \%)$ & $56(46.3 \%)$ & 8.9 days \\
\hline & P value & & & $\mathrm{P}=0.04$ & $P=0.03$ & \\
\hline
\end{tabular}

Among nutritional variables $87.5 \%$ and $87.5 \%$ of children who were not breastfed had very severe pneumonia and prolonged hospital stay respectively which was statistically significant; $59.3 \%$ and $81.5 \%$ of children with LBW had very severe pneumonia and prolonged hospital stay respectively which was statistically significant; $46.4 \%$ and $75.6 \%$ of children with incomplete immunization status had very severe pneumonia and prolonged hospital stay respectively which was statistically significant; $60.8 \%$ and $76.5 \%$ of Grade III and Grade IV PEM children with pneumonia had very severe pneumonia and prolonged hospital stay respectively, which was statistically significant; $51.5 \%$ and $90.9 \%$ of anaemic children with pneumonia had very severe pneumonia and prolonged hospital stay respectively, which was statistically significant [Table 4].

\begin{tabular}{|c|c|c|c|c|c|c|}
\hline \multicolumn{2}{|c|}{ Risk Factor } & \multirow{2}{*}{$\begin{array}{c}\begin{array}{c}\text { Admitted } \\
\text { with ALRI n }\end{array} \\
248\end{array}$} & \multirow{2}{*}{$\begin{array}{c}\begin{array}{c}\text { Severe } \\
\text { Pneumonia } \\
\text { n (\%) }\end{array} \\
183(73.8 \%)\end{array}$} & \multirow{2}{*}{$\begin{array}{c}\begin{array}{c}\text { Very Severe } \\
\text { Pneumonia } \\
\text { n (\%) }\end{array} \\
65(26.2 \%)\end{array}$} & \multirow{2}{*}{$\begin{array}{c}7 \text { Days of } \\
\text { Hospital } \\
\text { Stay n (\%) }\end{array}$} & \multirow{2}{*}{$\begin{array}{c}\begin{array}{c}\text { Mean } \\
\text { Duration of } \\
\text { Hospital Stay }\end{array} \\
9.13 \text { days }\end{array}$} \\
\hline \multirow{3}{*}{$\begin{array}{c}\text { Birth } \\
\text { weight }\end{array}$} & NBW & & & & & \\
\hline & LBW & 27 & $11(40.7 \%)$ & $16(59.3 \%)$ & $22(81.5 \%)$ & 11.05 days \\
\hline & $P$ value & & & $\mathrm{P}=0.0003$ & $\mathrm{P}=0.002$ & \\
\hline \multirow{4}{*}{$\begin{array}{l}\text { Breast } \\
\text { feeding }\end{array}$} & EBF & 192 & $163(84.9 \%)$ & $29(15.1 \%)$ & $86(44.8 \%)$ & 8.5 days \\
\hline & Partial & 67 & $29(43.3 \%)$ & $38(56.7 \%)$ & $47(70.1 \%)$ & 9.7 days \\
\hline & Never & 16 & $2(12.5 \%)$ & $14(87.5 \%)$ & $14(87.5 \%)$ & 12.1 days \\
\hline & P Value & & & $\mathrm{P}=0.000001$ & $P=0.00003$ & \\
\hline \multirow{3}{*}{$\begin{array}{l}\text { Immunizat } \\
\text { ion }\end{array}$} & Complete & 234 & $172(73.5 \%)$ & $62(26.5 \%)$ & $116(49.6 \%)$ & 9.18 days \\
\hline & Incomplete & 41 & $22(53.6 \%)$ & $19(46.4 \%)$ & $31(75.6 \%)$ & 10.15 days \\
\hline & $P$ value & & $\mathrm{P}=0.01$ & $P=0.002$ & & \\
\hline \multirow{4}{*}{ PEM } & Absent & 103 & $89(86.4 \%)$ & $14(13.6 \%)$ & $41(39.8 \%)$ & 8.74 days \\
\hline & Grade I + II & 121 & $85(70.2 \%)$ & $36(29.8 \%)$ & 67 (55.4\%) & 9.27 days \\
\hline & Grade III + IV & 51 & $20(39.2 \%)$ & $31(60.8 \%)$ & $39(76.5 \%)$ & 11.54 days \\
\hline & $P$ value & & & $\mathrm{P}=0.00001$ & $\mathrm{P}=0.00008$ & \\
\hline \multirow{4}{*}{$\begin{array}{l}\text { Anaemia } \\
\text { (WHO } \\
\text { Grading) }\end{array}$} & Mild (10-11) & 68 & $56(82.4 \%)$ & $12(17.6 \%)$ & $32(47.1 \%)$ & 8.4 days \\
\hline & $\begin{array}{c}\text { Moderate } \\
(7-10)\end{array}$ & 165 & $113(68.5 \%)$ & $52(31.5 \%)$ & $82(49.7 \%)$ & 9.5 days \\
\hline & Severe $(<7)$ & 33 & $16(48.5 \%)$ & $17(51.5 \%)$ & $30(90.9 \%)$ & 12.31 days \\
\hline & P Value & & & $\mathrm{P}=0.0009$ & $\mathrm{P}=0.006$ & \\
\hline
\end{tabular}

\section{DISCUSSION}

In the present study, ALRI was more common among infants (61.8\%). Severity of Pneumonia was found to be decreasing with increasing age. Sehgal $V$ et al. ${ }^{2} \mathrm{~N}$ Deivanayagam et al. and Anil Kumar et al. $^{3}$ also documented an inverse relationship between ALRI mortality and age. A large number of studies have shown that the incidence of viral respiratory illness peaks in infancy and steadily reduces with age. Hence, children below 1 year of age have high risk for severe ALRI and this group is to be targeted for early referral and intervention. This increased risk in infants is probably due to degradation of maternal antibodies, immaturity of adaptive immune system and cessation of breastfeeding. There is no statistically significant difference in incidence of very severe pneumonia or duration of hospital stay in males and females. Similar results were found by Anil Kumar et al. ${ }^{3}$
There was no statistically significant difference in the incidence of very severe pneumonia or duration of hospital stay in children of illiterate or literate mothers. But mean duration of hospital stay was more in children of illiterate mothers (10.32 days). Victoria et al. also reported that strong association between lack of parental education and risk of death from ALRI.4

In the present study, $32.5 \%$ and $57.9 \%$ of children with overcrowding in their houses had very severe pneumonia and prolonged hospital stay respectively, which was statistically significant. Ibrahim et al. ${ }^{5}$ and Mirji et al. ${ }^{6}$ observed that LRTI risk were found to be 1.47 and 4 fold increased when the number of people who live in the same room was $>3$.

So improvement in household ventilation might decrease incidence and severity of ALRI. 
In the present study, $56.9 \%$ and $72.2 \%$ of children with pneumonia belonging to lower socioeconomic class had very severe pneumonia and prolonged hospital stay respectively, which was statistically significant. Similar results were found by Tupasi et al. Lower social status is associated with crowded living conditions, higher smoking rates, potential for nutritional deficit and exposure to environmental pollutants. These factors may contribute to increase susceptibility to respiratory infections in these groups.

In the present study, $55.3 \%$ and $68.5 \%$ of children with mud/cow dung flooring in their house had very severe pneumonia and prolonged hospital stay respectively, which was statistically significant. Similar results were found by MR Savitha et al. ${ }^{7}$ Cracks and crevices which are common in these types of floors lead to breeding of insects and harbourage of dust.

In this study, $33.7 \%$ and $62.2 \%$ of children lived in households using cooking fuel other than LPG had very severe pneumonia and prolonged hospital stay respectively, which was statistically significant. The use of biomass fuels as the primary cooking fuel has been found by several studies to be associated with the risk of ALRI with odds ratios ranging from 2 to 4 (Murray et al. ${ }^{8}$ Broor et al. ${ }^{9}$ Smith et al. ${ }^{10}$ and Shah $\mathrm{N}$ et al. ${ }^{11}$ ). Johnson AW and Aderele WI found that children with ALRI who came from homes that burnt wood were 12.2 times $(p<0.0005)$ more likely to die than those coming from homes using kerosene or gas. In the present study, wood was used as a cooking fuel in almost all houses. These fuels are typically burnt in simple stoves with incomplete combustion and generate a lot of toxic products that adversely affect specific and nonspecific local defences of the respiratory tract. 10

In this study, $34.4 \%$ and $59.1 \%$ children with smokers in the household had significant risk for very severe pneumonia and prolonged hospital stay respectively, which was statistically significant. Similar results were found by Dharmage et al. ${ }^{12}$ and Shah $\mathrm{N}$ et al. ${ }^{11}$ Environmental Tobacco Smoke (ETS) is another indoor pollutant that reduces local defense mechanisms and predisposes children to respiratory illness. ${ }^{10}$

$59.3 \%$ and $81.5 \%$ of children with LBW had very severe pneumonia and prolonged hospital stay respectively, which was statistically significant. Dharmage et al.12 and Victoria CG et al. ${ }^{4}$ reported an association between LBW and severe ALRI.

$87.5 \%$ and $87.5 \%$ of children who were not breastfed had very severe pneumonia and prolonged hospital stay respectively, which was statistically significant. So measures to improve exclusive breastfeeding rate for the first six months is required. Victoria CG et al. ${ }^{4}$ study on ALRI specific mortality reported that relative to breastfed infants, those who also received artificial milk had 1.6 times and non-breastfed infants had 3.6 times risk of death due to ALRI. Breast milk in addition to passive protection seems to affect the infant's systemic immune response via multiple ways (Maturational, antiinflammatory, immune modulatory and antimicrobial). ${ }^{13}$

$46.4 \%$ and $75.6 \%$ of children with incomplete immunization status had very severe pneumonia and prolonged hospital stay respectively, which was statistically significant. Ibrahim et al. ${ }^{5}$ found that 1.69 fold increased risk of LRTI in patients with incomplete vaccination.

This is probably because mothers utilizing immunization services are better aware of health care facilities.
In this study, $60.8 \%$ and $76.5 \%$ of Grade III and Grade IV PEM children with pneumonia had very severe pneumonia and prolonged hospital stay respectively, which was statistically significant. Arpitha G et al. ${ }^{14}$ showed that severity of pneumonia increased with increasing severity of malnutrition being $40 \%$ in not significant malnutrition to $63 \%$ in significant malnutrition. It is well known that malnourished children have defective cell mediated immunity.

In this study, $51.5 \%$ and $90.9 \%$ of anaemic children with pneumonia had very severe pneumonia and prolonged hospital stay respectively, which was statistically significant. Karalanglin et al.15 and Anil Kumar et al. ${ }^{3}$ had identified anaemia as a significant risk factor increasing mortality from pneumonia by 10.88 times and 5.4 times respectively. So, prevention of anaemia will reduce the incidence and severity of pneumonia.

\section{CONCLUSIONS}

The present study identified many modifiable risk factors for ALRI, which had significant effect on outcome. The significant risk factors for children with pneumonia for very severe pneumonia and prolonged hospital stay were age $<12$ months, maternal illiteracy, overcrowding, low socioeconomic status, use of mud/cow dung flooring, biomass fuel usage, passive smoking, LBW, partial breast feeding and no breast feeding, partial immunization, PEM and anaemia. These risk factors can be tackled through effective health education of the community and appropriate initiatives taken by the government leading to healthy community and a healthy nation as a whole. The results of this study contribute favourably to the primary prevention and promotion of health aimed at acting more efficiently on the risk factors related to the health-disease process.

\section{REFERENCES}

1. Rudan I, Boschi Pinto C, Biloglav Z, et al. Epidemiology and etiology of childhood pneumonia. Bulletin of the World Health Organization 2008;86:408-416.

2. Sehgal V, Sethi GR, Sachdev HP. Predictors of mortality in subjects hospitalized with acute lower respiratory tract infections. Indian Pediatr 1997;34:213-219.

3. Anil Kumar, Erina Saha, Deepak Patra, et al. Outcome of acute lower respiratory tract infection in children. Indian Medical Gazette 2011;394-399.

4. Victora CG, Smith PG, Barros FC, et al. Risk factors for death due to respiratory infections among Brazilian infants. Int J Epidemiol 1989;18:918-925.

5. Ibrahim Silfeler, Ibrahim Cansaran Tanidir, Vefik Arica. Risk factors for lower respiratory tract infections in children. Pak J Med Sci 2012;28(3).

6. Mirji G, Shashank KJ, Shrikant SW, et al. Sociodemographic profile of under five children admitted for acute lower respiratory tract infections in a tertiary care hospital. Int J Contemp Pediatr 2014;1(2):106-109.

7. Savitha MR, Nandeeshwara S, Pradeep Kumar MJ, et al. Modifiable risk factors for acute lower respiratory tract infections. Indian J Pediatr 2007;74:477-82. doi:10. 1007/s1209800700813. 
8. Murray el, brondi l, Kleinbaum D, et al. Cooking fuel type, household ventilation, and the risk of acute lower respiratory illness in urban bangladeshi children: a longitudinal study. Indoor air 2012;22:132-9. doi:10.1111/j.16000668.2011.00754.x

9. Broor S, Pandey RM, Ghosh M, et al. Risk factors for severe acute lower respiratory tract infection in underfive children. Indian Pediatr 2001;38:1361-9.

10. Smith KR, Samet JM, Romieu I, et al. Indoor air pollution in developing countries and acute lower respiratory infections in children. Thorax 2000;55:518-531.

11. Shah N, Ramankutty V, Premila P, et al. Risk factors for severe pneumonia in children in south Kerala: a hospitalbased case control study. J trop Pediatr 1994;40:201-6. doi:10.1093/ tropej/40.4.20.
12. Dharmage SC, Rajapaksa IC, Fernando DN. Risk factors of acute lower respiratory tract infections in children under five years of age. Southeast asian J trop Med Public Health 1996;27:107-10.

13. Kelly D, Coutts AGP. Early nutrition and the development of immune function in the neonate. Proc Nutr Soc 2000;59:177-185.

14. Arpitha G, Rehman MA, Ashwitha G. Effect of severity of malnutrition on pneumonia in childern aged $2 \mathrm{M} 5 \mathrm{Y}$ at a tertiary care center in Khammam, Andhra Pradesh: a clinical study sch. J App Med Sci 2014;2(6E):3199-3203.

15. Karalanglin Tiewsoh, Rakesh Lodha, Ravindra M Pandey, et al. Factors determining the outcome of children hospitalized with severe pneumonia. BMC Pediatrics 2009;9:15. doi:10.1186/1471 2431915 . 